\title{
THE EFFECT OF COMMUNICATIVE LANGUAGE TEACHING ON STUDENTS' SPEAKING SKILL
}

\author{
Euis Yanah Mulyanah ${ }^{1}$ \\ Ishak ${ }^{2}$ \\ Ratih Kusuma Dewi ${ }^{3}$ \\ Dosen FKIP Univ Muhamadiyah Tangerang ${ }^{1}$, Dosen FE Univ Muhammadiayah Tangerang ${ }^{2}$, \\ Alumni Mahasiswa FKIP Univ Muhammadiyah Tangerang3 \\ Jl. Jendral Sudirman No. 40, Modern Cikokol, Tangerang ${ }^{1,2,3}$ \\ Email: euis@umt.ac.id ${ }^{1)}$, ishak@umt.ac.id ${ }^{2)}$, ratihkusumadewi497@yahoo.co.id ${ }^{3)}$
}

\begin{abstract}
The aims of this research were to find out whether there are good response and improvement of students' speaking skill between before and after being taught through Communicative Language Teaching (CLT). The samples of this research were the VIII A and VIII B class of the Eighth Grade of SMP Negeri 21 Tangerang in academic year 2015/2016. The researcher used non-equivalent control group design. The instrument was oral test. The result of the research showed that there was improvement of the students' speaking skill in actively communicative by using CLT. The result of $t$ test showed that $t$ was bigger than $t_{\text {table. }}$. The result of $t_{\text {count }}$ was 4.2105 and $t_{\text {table }}$ was 2.0021 . It means that the researcher's hypothesis $\left(H_{1}\right)$, there is significant difference of post-test scores between experiment class and control class is accepted. The average score of pre-test in experiment class is 67.33 while the average score of pre-test in control class is 66.50. The average of the post-test score in experiment class was 83.00 while the average of the post-test score in control class was 75.00. It showed that CLT can improve the students' speaking skill.
\end{abstract}

Keywords: Communicative Language Teaching (CLT), Speaking Skill.

\section{INTRODUCTION}

Speaking is the ability to communicate orally continues to be an essential skill for students at school and university it is important also for the students to practice their capability and their understanding on how to send idea and how to spell word well[1]. In this case, the students' motivation and interest are very needed to make the process of their understanding more easily. Even though speaking skill is important in order to support the skill in English, in fact, many of English learners are often faced with the problems of speaking skill. There were some problems that are encountered by students at SMP Negeri 21 Tangerang in speaking. Firstly, the students' limitation in mastering the component of speaking, therefore they feel hard to express their ideas in English. Secondly, the students are rarely practicing their English either in or out of the class. Thirdly, the students felt that English is very difficult. There are many ways to help the students to improve their speaking skill. One of the ways is through CLT method. CLT is the method in which the students are asked to use the language for communication in real situation and for successful oral communication students need a thorough in-depth instruction and practice [2].

\section{PROBLEM OF THE RESEARCH}

Based on the background of the study above, the problems can be stated. The students have limitations in speaking English, the students rarely practice their English either in or out of the class and the students feel that English is very difficult and problems become also from proper language environments [3]. The problems can be stated in such formulation as follows. 
"Is there any significant difference of students speaking skill taught by CLT and those taught by conventional method of the eighth grade students of SMPN 21 Tangerang?". Based on the formulation of the problem stated, this research is aimed to find out the significant difference of students speaking skill taught by CLT and those taught by conventional method of the eighth grade students of SMP Negeri 21 Tangerang.

\section{THEORETICAL FOUNDATION}

\section{Speaking}

Speaking is one of four language skills which are very important to be mastered by students in order to be good communicator and the ability to speak English fluently and accurately opens up wider opportunities to achieve success in life because speaking is the most important thing in communicate with other people [4]. According to Thornbury states, "speaking is interactive and requires the ability to co-operate in the management of speaking turns [5]. It also typically takes place in real time, with little time for detailed planning”. In my point of view, speaking is crucial part of second language learning and teaching to get success in communication. Speaking can be used all the time in their daily life and environments help to create a safe learning zone where learners could feel more comfortable making errors in their speaking [6]. People will be able to communicate with others and express their ideas easily. Based on the definitions above, it can be concluded that speaking is crucial part in language learning to get success in communication with other people. Speaking can be used all the time in their daily life. If people have many languages, they can express their ideas easily. The researcher chose a short conversation to practice the students in the class assessed based on the types of speaking as follows: 1) Monologue. In monologue, when a speaker uses spoken language for any length of time, like in speech, lecture, storytelling, newscast, etc., the listener must process long stretches of speech without any interruption. The stream of the speech will go on without heeding whether the listener comprehends or not. Monologue its self is divided into two kinds, planned and unplanned. Planned usually refer little redundancy and are relatively difficult to comprehend. Whereas unplanned manifest more redundancy which makes for ease in comprehension, but the presence of more performance variable and other hesitations, can help or hinder comprehension. 2) Dialogue. Contradictory with monologue, dialogue involves two or more speaker and can be subdivided into interpersonal and transactional. An interpersonal language is a dialogue with the purpose is to promote social relationship between speakers. On the other hand, transactional language is a dialogue which involves two or more speakers and the purpose is to convey propositional or factual information [7].

In line with the theories above, it can be concluded that there are two types of speaking, Monologue and dialogue. Both of them have different purpose. Monologue is singular speaking which is only intended to convey our intention, while dialogue is plural speaking consist of the least two people, speaker and hearer, who make an interaction. One transmits the message orally and another receives and processes it in his mind in order to understand the meaning of the message for the purpose of replying to the speaker's message orally too.

The scoring categories of speaking rubric are important elements needed to be scored in speaking skill such as: grammar, vocabulary, comprehension, fluency, and pronunciation in the following [8]: 
Table 1. The Speaking Scoring Sheet

\begin{tabular}{|c|c|c|}
\hline Aspect & Score & Details \\
\hline \multirow{5}{*}{ GRAMMAR } & 1 & $\begin{array}{l}\text { Grammatical errors so severe that it is difficult to } \\
\text { understand. }\end{array}$ \\
\hline & 2 & $\begin{array}{l}\text { A lot of grammatical errors that impede meaning and } \\
\text { often rearranging sentences. }\end{array}$ \\
\hline & 3 & $\begin{array}{l}\text { Able to speak the language with sufficient structural } \\
\text { accuracy. }\end{array}$ \\
\hline & 4 & $\begin{array}{l}\text { Able to use the language accurately on all levels normally } \\
\text { pertinent to professional needs. }\end{array}$ \\
\hline & 5 & Equivalent to that of an educated native speaker. \\
\hline \multirow{5}{*}{ VOCABULARY } & 1 & $\begin{array}{l}\text { Inadequate to express anything but the most elementary } \\
\text { needs. }\end{array}$ \\
\hline & 2 & Has limited vocabulary to express themselves simply. \\
\hline & 3 & $\begin{array}{l}\text { Able to speak the language with sufficient vocabulary to } \\
\text { participate effectively. }\end{array}$ \\
\hline & 4 & Can understand and participate in any conversation. \\
\hline & 5 & Speech on all levels is fully accepted. \\
\hline \multirow{5}{*}{ COMPREHENSION } & 1 & $\begin{array}{l}\text { Can understand simple questions and statements if } \\
\text { delivered with slowed speech or repetition. }\end{array}$ \\
\hline & 2 & $\begin{array}{l}\text { Can get the gist of most conversations that require no } \\
\text { specialized knowledge. }\end{array}$ \\
\hline & 3 & $\begin{array}{l}\text { Comprehension is quite complete at a normal rate of } \\
\text { speech. }\end{array}$ \\
\hline & 4 & Can understand any conversation. \\
\hline & 5 & Understand of any conversation without any difficulty. \\
\hline \multirow{5}{*}{ FLUENCY } & 1 & Lack of fluency. \\
\hline & 2 & Lack of fluency but can handle with confidence. \\
\hline & 3 & Able to speak the language with sufficient fluency. \\
\hline & 4 & Able to use the language fluently on all levels. \\
\hline & 5 & Has complete fluency. \\
\hline
\end{tabular}


1 Errors in pronounciation are frequent.

$\begin{array}{lll}\text { PRONUNCIATION } & 2 & \text { Accent is intelligible though often quite faulty. } \\ 3 & \text { Errors never interfere with } \\ 4 & \text { Errors in pronunciation are quite rare. } \\ 5 & \text { Easy to understand. }\end{array}$

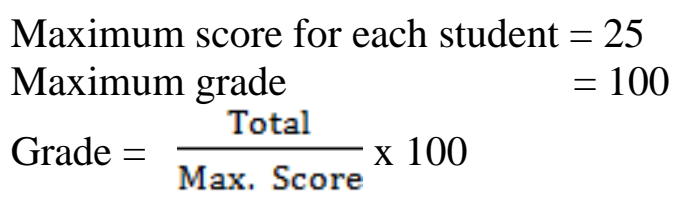

2. Communicative Language Teaching (CLT)

According to Richard and Rogers states that "Communicative Language Teaching is regarded more as an approach since, the aims of CLT are to make the communicative competence the goal of language teaching and to develop procedures for the teaching of the four language skills that acknowledge the interdependence of language and communication" [9]. Based on the definition above, the researcher states that CLT is one of method which is designed to help the English learners to use the target language for daily communication that can improve the student's knowledge and skill especially in speaking skill. Larsen and Freeman states "The most obvious characteristic of CLT is that almost everything that is done with a communicative intent. Students use the language a great deal through communicative activities such as games, role plays, and problem solving tasks". Based on the opinions above, the researcher states that characteristic of CLT is emphasized on the function of language than language system and CLT has many communicative activities that can be used in the learning process such as games, role plays and problem solving tasks. Dianne Larsen and Freeman states "The goal of the CLT is to enable students to communicate in the target language. This student's need knowledge of the linguistic forms, meanings, and functions". Based on the above, it can be concluded that purpose of CLT is developing communicative competence and acquire of target language. There are many effectiveness aspects in CLT to improve student's speaking skill such as they are reviewing many techniques and materials. These are authentic materials, scrambled sentences; language games, picture strip story, and role play [10].

\section{Teaching Speaking Using CLT}

To help students develop communicative efficiency in speaking, the teacher can use a balanced activities approach that combines language input, structured output, and communicative output. Now many linguistics and ESL teachers agree on that students learn to speak in the second language by "interacting". CLT method serves best for this aim. CLT method provides activities and combinations as follow: Information-gap activities, Role-play, Memorization of Dialogues [11].

4. Hypothesi

The hypothesis of this research is formulated as follows:

a. Hypothesis of Pre-test 
$\mathrm{H}_{\mathrm{O}}$ : There is no difference between experiment class and control class in term of students' speaking skill for eighth grade students of SMP Negeri 21 Tangerang in academic year 2015/2016.

$\mathrm{H}_{1}$ : There is difference between experiment class and control class in term of students' speaking skill for eighth grade students of SMP Negeri 21 Tangerang in academic year 2015/2016.

b. Hypothesis of Post-test

$\mathrm{H}_{\mathrm{O}}$ : There is no difference between the students' speaking skill taught by CLT and those taught by conventional method of the eighth grade students of SMP Negeri 21 Tangerang in academic year 2015/2016.

$\mathrm{H}_{1}$ : There is difference between the students' speaking skill taught by CLT and those taught by conventional method of the eighth grade students of SMP Negeri 21 Tangerang in academic year 2015/2016.

\section{RESEARCH METHODOLOGY}

This research was conducted at SMPN 21 Tangerang. It is located on Jl. Halim Perdana Kusuma. The implementation of the research is carried out from February to August 2016. The research methodology used experimental research design. This research tries to describe the effect of treatment by using CLT and conventional method toward students' speaking skill. Population in this research is Eighth Grade year students of the SMP Negeri 21 Tangerang in academic year 2015/2016. The population of this research are 230 students and the researcher used purposive sampling because VIII A and VIII B have same scores in English. The researcher will choose VIII A as the experiment class and VIII B as the control class.

Table 2. The Sample of the Research

\begin{tabular}{crcc}
\hline No & Class & Number of Students & Class \\
\hline 1 & VIII A & 30 & Experiment \\
2 & VIII B & 30 & Control \\
& Total & \multicolumn{2}{c}{60 students } \\
\hline
\end{tabular}

The technique of collecting data is test. There were two kinds of test in this research. They were pre-test and post-test for speaking skill. The technique of data analysis is calculating t-test (pre-test - post-test), Normality test to know the normality of the data before and after given the treatment. Homogeneity test used to get assumption that the sample is from homogen population or not.

\section{RESEARCH FINDINGS}

Based on the result of research in experiment class before applying CLT as the teaching method, the minimum score is 55 and the maximum score is 80 . By analyzing the central tendency, the researcher got the data as follows: the score of mean was 69.33; the score of median was 68.85; and the score of mode was 67.5. By analyzing the dispersion, the researcher got the data as follows: the score of range was 25; the score of standard deviation was 7.27; and the score of variance was 52.85 . 


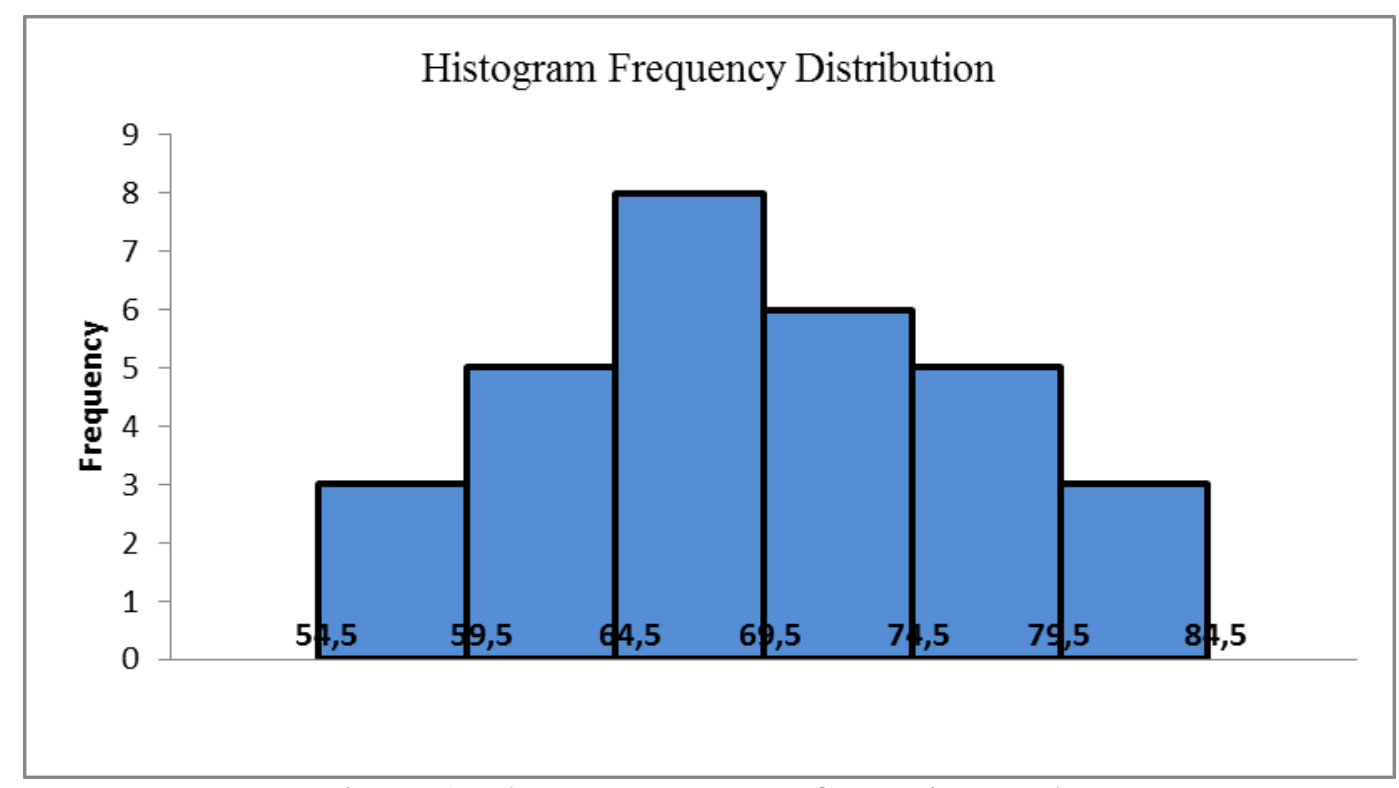

Figure 1. The pre-test score of experiment class

Based on the result of research in control class before applying CLT as the teaching method, the minimum score is 55 and the maximum score is 80 . By analyzing the central tendency, the researcher got the data as follows: the score of mean was 68.50; the score of median was 68.75; and the score of mode was 70.5. By analyzing the dispersion, the researcher got the data as follows: the score of range was 25; the score of standard deviation was 7.08; and the score of variance was 50.12.

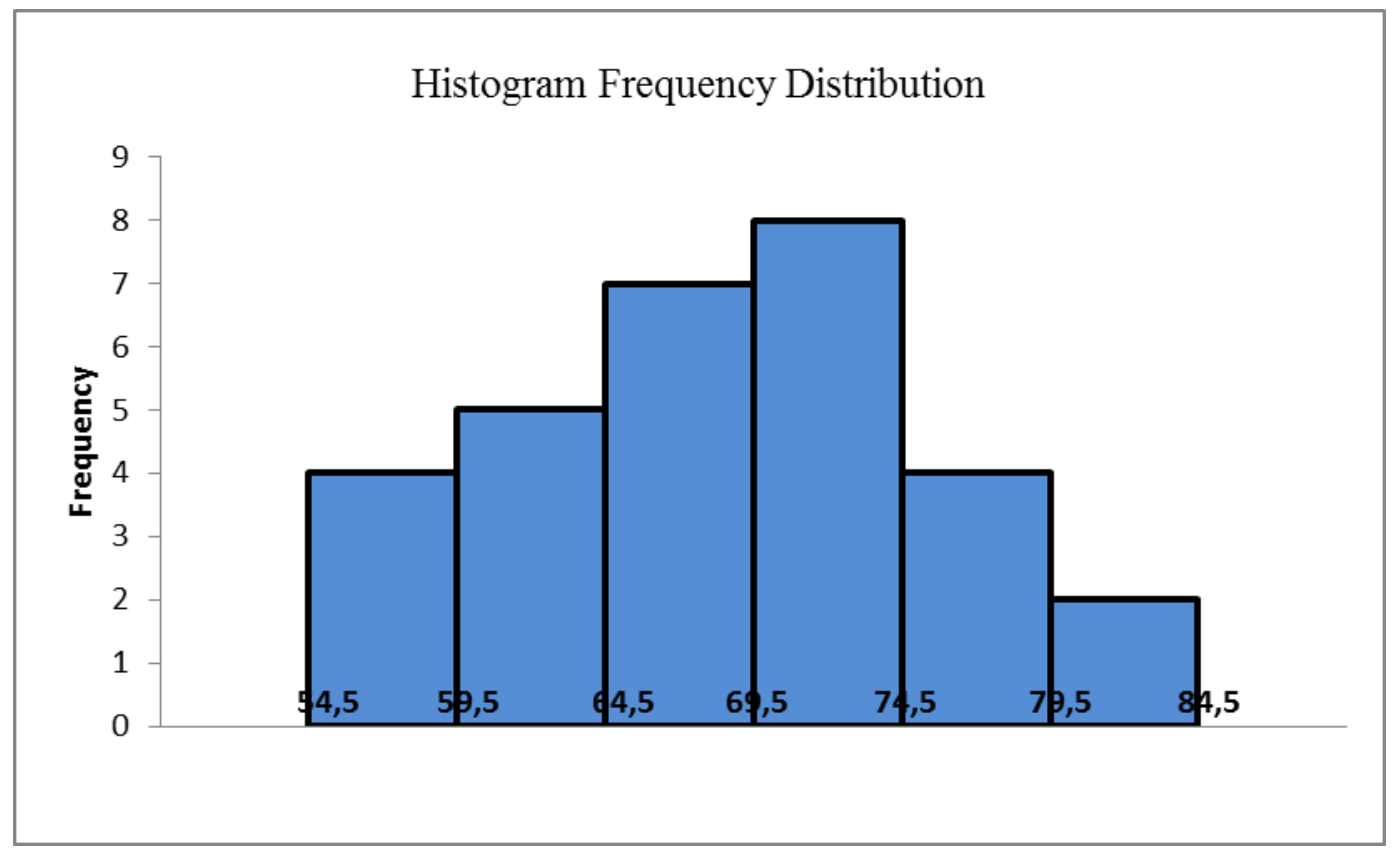

Figure 2. The Pre-test Score of Control Class

The data was taken after the teaching and learning process was conducted by using CLT as the teaching method. This data would be used to know that CLT was effective or not as the teaching method. CLT was effective if the post-test score was higher than pre-test score. The maximum score is 95 and the minimum score is 70 . By analyzing the central tendency, the researcher got the data as follows: the score of mean was 85.00; the score of median was 85.2; and the score of mode was 86.15 . By analyzing the dispersion, the researcher got the data as 
follows: the score of range was 25; the score of standard deviation was 7.59 ; and the score of variance was 57.60 .

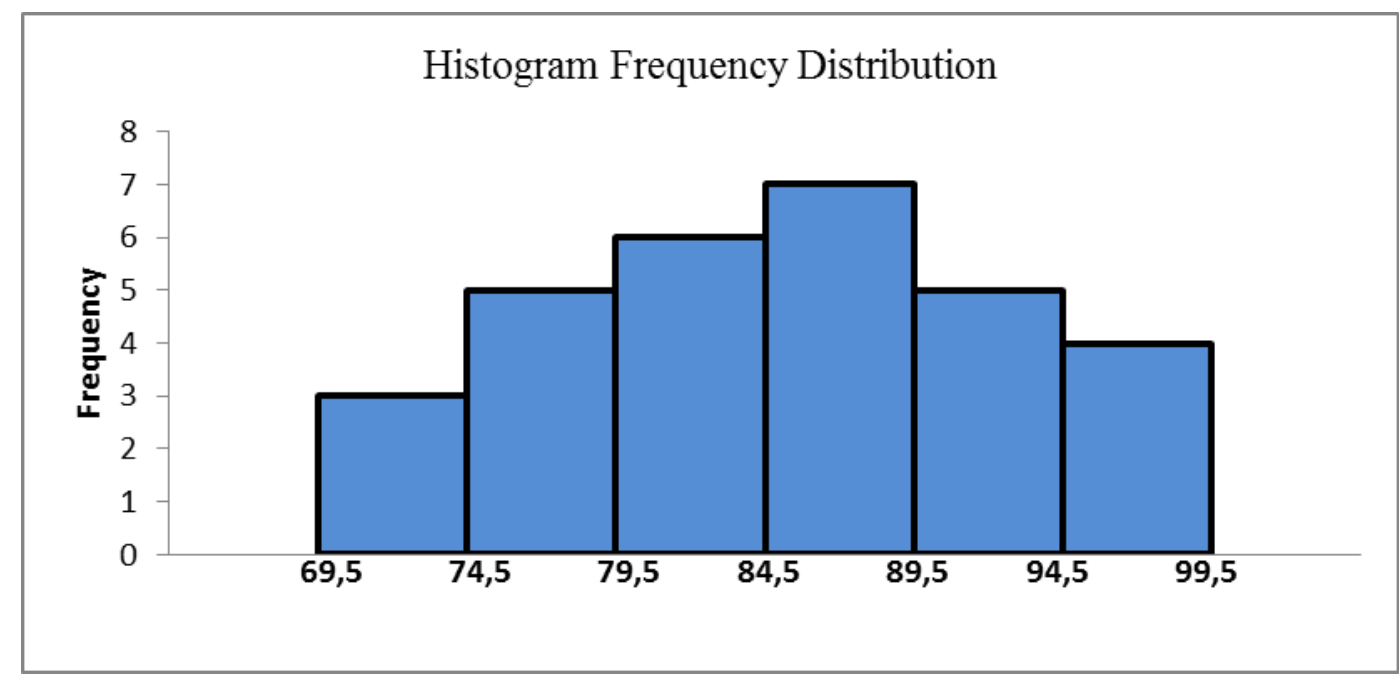

Figure 3: The Post-test Score of Experiment Class

The data was taken after the teaching and learning process was conducted by using CLT as the teaching method. This data would be used to know that CLT was effective or not as the teaching method. CLT was effective if the post-test score was higher than pre-test score. The maximum score is 90 and the minimum score is 65 . By analyzing the central tendency, the researcher got the data as follows: the score of mean was 77.00; the score of median was 77.35; and the score of mode was 80.3. By analyzing the dispersion, the researcher got the data as follows: the score of range was 25; the score of standard deviation was 6.95; and the score of variance was 48.30 .

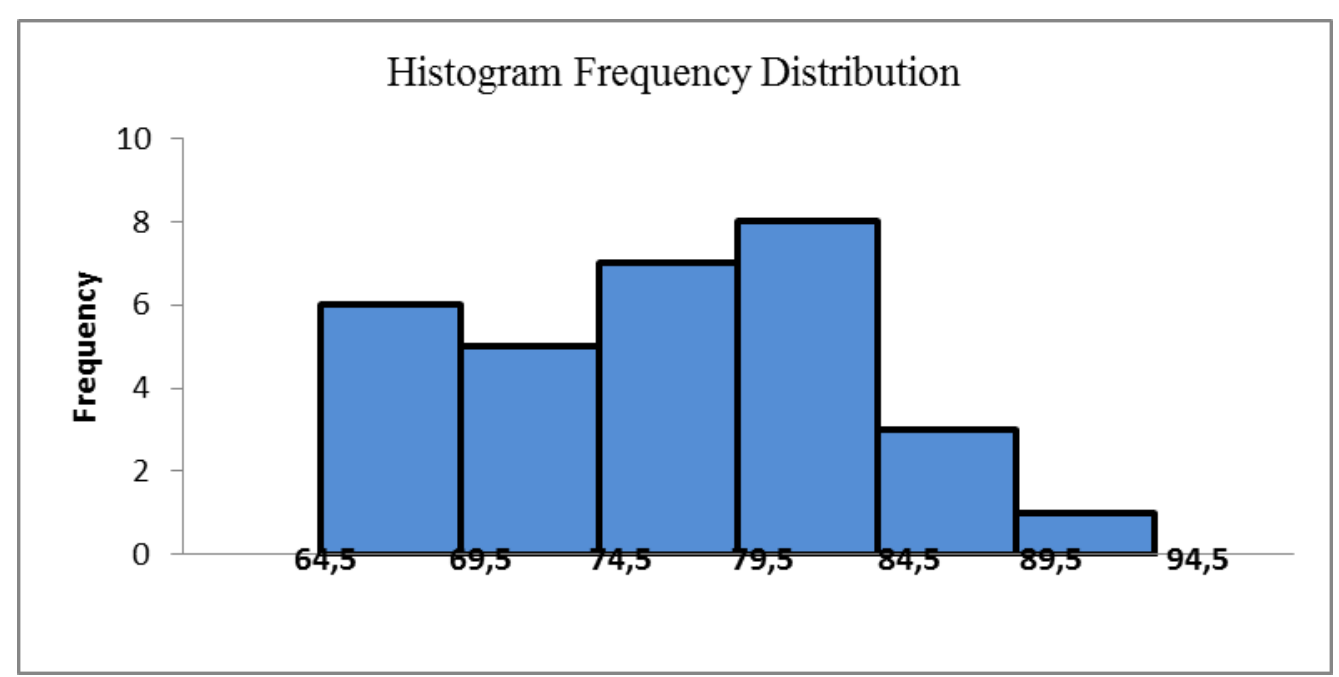

Figure 4: The Post-test Score of Control Class

The Analysis of Data from To test the normality of data, the researcher used Liliefors

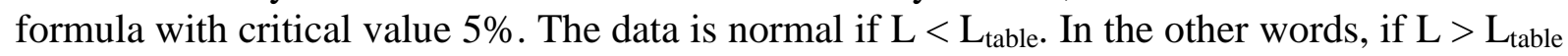
the data distributed is not normal. 
Table 2. The Result of Normality Test

\begin{tabular}{clccc}
\hline & & $\mathbf{L}$ & $\mathbf{L}_{\text {table }}$ & Conclusion \\
\hline \multirow{2}{*}{ Pre-test } & Experiment Class & 0.155 & & Normal \\
& Control Class & 0.117 & \multirow{2}{*}{0.161} & Normal \\
\multirow{2}{*}{ Post-test } & Experiment Class & 0.118 & & Normal \\
& Control Class & 0.128 & & Normal \\
\hline
\end{tabular}

The researcher used Fisher with critical value 5\% to test the homogeneity of data. The data is homogeneous if $\mathrm{F}<$ Ftable. In other words, the data is not homogeneous if $\mathrm{F}>$ Ftable.

Table 3 The Result of Homogeneity Test

\begin{tabular}{ccccc}
\hline & & F & Ftable & Conclusion \\
\hline \multirow{2}{*}{ Pre-test } & $\begin{array}{c}\text { Experiment Class } \\
\text { Control Class }\end{array}$ & 1.05 & & Homogeneous \\
Post-test & $\begin{array}{c}\text { Experiment Class } \\
\text { Control Class }\end{array}$ & 1.19 & 1.86 & \\
& & & & Homogeneous \\
\hline
\end{tabular}

In this research, the researcher used t-test formula for hypothesis testing of the data to find out the effect of CLT in improving students' speaking skill. The average score of pre-test in experiment class is 67.33 while the average score of pre-test in control class is 66.50 . The average score of post-test in experiment class is 83.00 while the average score of post-test in control class is 75.00. Based on the result of calculation of data analysis by using t-test, the value of $t_{\text {count }}$ is 4.2105 and the value of $t_{\text {table }}$ is 2.0021 . Because $t_{\text {count }}$ is bigger than $t_{\text {table, }}$ it means that $\mathrm{H}_{\mathrm{O}}$ is rejected and $\mathrm{H}_{1}$ is accepted. In other words, there is significant difference of post-test scores between experiment class and control class in term of students' speaking skill of the eighth grade students of SMP Negeri 21 Tangerang.

\section{CONCLUSION}

Based on the data analysis previously, the researcher would like to make a conclusion by showing the result of t-test and the differences of the average scores of post-test in experiment class and control class. The result of conclusion of t-test shows that $t$ is bigger

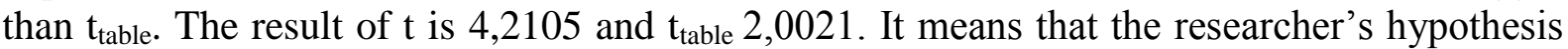
$\left(\mathrm{H}_{1}\right)$, there is significant difference of post-test scores between experiment class and control class in term of students' speaking skill of the eighth grade students of SMPN 21 Tangerang, is accepted. The average of the post-test score in experiment class is 83 while the average of the post-test score in control class is 75 . It shows that Communicative Language Teaching can improve the students' speaking skill.

Based on the explanation above, the researcher conclude that Communicative Language Teaching is a suitable method to teach speaking. It can solve the problems that are faced by the students such as they have limitations in speaking English and they do not have the motivation to learn English. By teaching speaking through CLT, the students can speak English fluently and make them confident. 


\section{REFERENCES}

[1] N. Al-Nouh, M. Abdul-Kareem, H. Taqi, "EFL College Students' Perceptions of the Difficulties in Oral Presentation as a Form of Assessment". International Journal of Higher Education Vol.4 No.1 January 12, 2015. Published by Sciedu Press: Kuwait, 2015.

[2] Živković. S, “The Importance of Oral Presentations for University Students". Mediterranean Journal of Social Sciences Vol.5 No.19 August 2014. MCSER Publishing: Rome-Italy, 2014.

[3] Pathan, Aldersi, Alsout, "Speaking in their Language: An Overview of Major Difficulties Faced by the Libyan EFL Learners in Speaking Skil". IJ-ELTS Vol.2 No.3 September, 2014. eltsjournal: Sebha, Libya 2014.

[4] A. Reza, S. Beniss, V. Edalati, "The impact of pushed output on accuracy and fluency of Iranian EFL 1 earners ' speaking”. Iranian Journal of Language Teaching Research Vol.2 No.2 July, 2014, Urmia University Press: Iran 2014.

[5] Thornbury, S. (2005). How to Teach Speaking. England: Longman.

[6] Rodrigues, P.,D., Vethamani, M., E., "The Impact of Online Learning in the Development of Speaking Skills" Journal of Interdisciplinary Research in Education (JIRE) Vol. 5, Issue 1, 2015, pp. 43-67, Taylor's Press: Malaysia, 2015.

[7] Mulyanah, E., Y., "Improving Student's Speaking Skill trough Cooperative Learning at $8^{\text {th }}$ Grade of SMPN 1 Legok Kab. Tangerang in Academic Year 2013/2014". Jurnal DINAMIKA Vol. 1 No. 1 November 2015. Universitas Muhammadiyah Tangerang: Indonesia 2015.

[8] Brown, H., D.,. 2004. Language Assessment:Principles and Classroom Practices. USA: Pearson Education.

[9] Setiyadi, et.,al,. 2009. TEFL 2. Jakarta: Universitas Terbuka.

[10] Laresen, D., \& Freeman. 2000. Technique and Principles in Language Teaching.UK: Oxford University Press.

[11] Agustina. 2013. Applying Communicative Language Teaching (CLT) to Develop SpeakingSkill in EFL Classrooms. http://bdkpalembang.kemenag.go.id/applying-communicative-language teaching-clt/ (accessed March, 2015). 